\title{
Code Mixing in the Student Presentation of PBSI Unipa Surabaya
}

\author{
Ira Eko Retnosari \\ Universitas PGRI Adi Buana Surabaya \\ Surabaya, Indonesia \\ ira@unipasby.ac.id
}

\begin{abstract}
This article intends to (1) describe the mixed form in the student presentation of PBSI Unipa Surabaya, (2) describe the type of code mix in the student presentation of PBSI Unipa Surabaya, and (3) describe the code mixed background in the student presentation of PBSI Unipa Surabaya. This research uses qualitative approach by using descriptive method. The data in this study are words, phrases, and clasuses containing mixed code and the source data is utterance in the presentation of students. In this research, used technique of listen, technique of participate, and note technique in collecting data. Data collection procedures include (1) presentation recording, (2) presentation presentation, (3) presentation transcription, (4) marking of mixed code transcription results, and (5) encoding data. Data analysis procedures in this study include (1) data collection, (2) data classification, (3) data expansion, and (4) data deduction. Data analysis procedures in this study include (1) data collection, (2) data classification, (3) data expansion, and (4) data conclution. Based on the results of data analysis, it can be concluded that (1) (2) the type of code mix in the presentation of UNIPA Surabaya students is mixed code inside and outside code mix, and (3) the code mixed background in student presentation of PBSI Unipa Surabaya is attitudinal type dan linguistic type.
\end{abstract}

Keywords-code mixing; type code mixing; code mixing background; the student presentation

\section{INTRODUCTION}

A person in communication must have language skills and skills to express the language in accordance with the functions and situations and norms of usage in its social context. In communicating, the norms are visible from verbal behavior and nonverbal behavior.

However, on the other hand linguistic problems often arise. This is due to the rapidity of science so that people also want to follow the development of the times through development science and technology. For example, the issue of bilingualism, which is currently not uncommon finds societies capable of using two or more languages in speaking.
Bilingualism is the mastery of at least two languages, namely the first language and the second language (Rahardi, 2001:p. 16). Bilingualism can also be interpreted as the ability or habit possessed by speakers in using the language. Many aspects relate to bilingual studies, such as social, individual, pedagogical, and psychological aspects. In that case, a bilingual person is able to influence the person who speaks with him so that the person is interested in using the same language and using two languages to speak with others. This will become a habit that will arise other language problems, such as diglossia, code change, and mix code.

Saddhono (2012: p. 75) explained that the mixed code is the use of two or more languages by inserting one language element into another language. In this case, speakers insert elements of other languages while using a particular language. This mixedcode event is one of the most common linguistic phenomena in everyday life. The use of code mix can occur in a place that has a pluralistic society such as on campus.

In general, students come from various regions. Based on that, students may interfere with code when communicating. In formal situations, it should be avoided because the code should be used in good and correct Indonesian. However, based on the observation of the mixed code still occurs when the student presents. This presents with mixed code, mixed code, and code mixed backgrounds.

\section{THEORETICAL REVIEW}

\section{A. Code Mixing}

The use of two languages in communicating to speakers will result in mixed code. Achmad and Abdullah (2012) define that mixed code is an event of the use of another language in one situation. Other languages can be phrases and clauses. Phrases consisting of clauses and mixed phrases and each of these clauses does not support each function (separate). In line with Kachru's opinion (in Suwito, 1983: p. 76). He said that code mixing is the use of two or more languages by consistently inserting one element into another language. Code mixing 
occurs when a language speaker, for example, the Indonesian language incorporates elements of the local language into Indonesian language talks. In other words, someone who speaks the main code of the Indonesian language that has its economic function, while the local language code involved in the main code is only certain parts without function or economy as a code.

Meanwhile, Nababan (in Aslinda and Syafyahya, 2010) argues that the prominent feature of this code mixing is the reliance or informal situation. The mixing of the language is caused by the reliance or habits of the speaker and usually occurs in an informal situation. In the case of a formal language, it is rare to mix code, if there is a mixed code in that state because there is no proper word or phrase to replace the language being used so that it is necessary to use words or expressions from local languages or foreign languages.

From some of the above experts' opinion, it can be concluded that code mixing is the event of using two or more language codes by speakers, one of the codes used only in the form of fragments of words (lexical particles), words, phrases, and clauses of another language into one situation. One of the grammatical codes does not meet the grammatical requirements as well as the relaxation of their speakers without any specific reasons with a more general form of language or in a relaxed situation. Therefore, code interpolations are often used when an informal situation occurs when code mixes occur during the formal situation because no word or expression can be represented so that the code or language element or foreign language is used.

\section{B. Mixed Type of Code}

Suwito (1983: p. 76) divides the type of mixed code into two, namely:

\section{1) Mix the Code out (Outer Code Mixing)}

It is said to mix the code out (extern) when between the source language and the language politically. These external code mixes occur because the ability of the target does not have a kinship relationship, geographically, geologically or intellectually high, radiates a moderate value. Thus, this type of code mix is the alienation between the languages involved. For example, Indonesian-English.

\section{2) Mix the Code into (Inner Code Mixing)}

Mixed code in is a mix of code that comes from the original language (intern) with all the variations. It is said mixed code into if between source language with target language still have kinship relation geographically and also geanologis, one language with other language is part so that this interlanguage relation is vertical. For example, Indonesian-Java language-Batak language and other regional languages.

\section{Causes Codes Mixing}

Codes mixing can be caused by multilingual speech societies which means having the ability to communicate using more than one language, but the code mix has no clear intent and purpose to use because the code mix used is usually not recognized by the speaker of the knowledge of the foreign language it knows. According Suwito (in Rokhman, 2013: p. 38-39), as for the causes of the mixed code include:

\section{1) Identification of Roles}

Included in role identification are the social, educational, and group status of the speakers or speakers of that language.

\section{2) Identify the Variety}

The variation identification is determined by the language spoken by the speaker at the time of coding, which will take place in the social status hierarchy.

\section{3) The Desire to Explain and Interpret.}

Included in this factor is the appearance of mixed-code events that signal attitudes and the speaker's relationship to others, and the relationships of others to them.

The background of mixed codes according to Suwito (1983: p. 77), is categorized into two types:

\section{1) The Type of Background on the Attitude of the} Speaker (Attitudinal Type)

Types of background in attitudes include to refine the phrase, to demonstrate its ability, as well as the development and introduction of new cultures.

2) The type of background in language (linguistic type)

Types of language backgrounds include more memorable, non-harmony, word limitations, and result or result.

\section{Presentation}

Triwidodo and Kristanto (2004: p. 157) argue that the presentation is a form of oral report on a particular fact to the communicant. This means that presentation is one form of verbal communication is one form of communication used to convey messages to other parties through writing or oral. With the delivery of messages in writing or oral, it is expected that people can understand what is delivered by the sender of the message well. Meanwhile, Sutomo (2007:1) said that the presentation is an active activity of a speaker who convey and communicate ideas and information to a group of audiences. From these statements, a conclusion can be drawn up if presentations are actively carried out by involving people other than the speaker so that the speaker should be able to make an interesting presentation to follow. Generally, the audience gets bored because the topic being discussed is less 
interesting or the speaker is less able to deliver the material well.

Triwahyuni and Kadir (2004: p.1) say that presentation is an important activity in communicating an idea to others with a variety of purposes, for example to attract an audience to buy products, use services, or for the benefit of others. This explains that the presentation has a variety of purposes. The delivery of the presentation is tailored to the purpose and purpose of the presentation. From some understanding above, can be drawn conclusion about understanding of presentation. Thus, a presentation is defined as an oral communication activity regarding the delivery of ideas or certain facts to others with various purposes.

\section{Methodology OF StUdy}

This article uses a qualitative approach because this article reveals logically, systematically, and empirically against the social phenomena that occur around us to be reconstructed to reveal the truth beneficial to the life of society and science. The research method used in this article is descriptive method. This is because the data collected and analyzed are described descriptively. Another reason that this research is a skin research is the presentation of the results of this study in the form of description of the object and data collection with a natural setting. The data in this study are words, phrases, and clauses containing mixed code. The source of data in this study is utterance in the student presentation.

The techniques of data collection in this article are simak techniques and skillful techniques. Data collection procedures include (1) presentation recording, (2) presentation presentation, (3) presentation transcription, (4) marking of mixed code transcription results, and (5) encoding data. Data analysis procedures in this study include (1) data collection, (2) data classification, (3) data expansion, and (4) data deduction.

\section{FINDING AND DISCUSSION}

Based on data analysis, it can be described as follows.

\section{A. Mixed Type Code}

The types of code mix found in student presentations are two, namely (1) mixing code into (inner code mixing) and (2) mixing outer code (outer code mixing). The following will be exposed to both types of mixed code.

\section{1) Inner Code Mixing}

a) Level of education, the level of education is also continuously different third is mentally, mentally his son was including the cause of the tone that can emerge, for example his brave son appears certainly Nurs lek cubs child Nurs.

b) Means over yo code? c) Merauke knows what that means in the Indonesian language. Like that, mbulet or understand?

d) Well, while carrying on the head is not there, now that he was looking for the equivalent of the word in the language of Java or the local language, nyunggih yes.

The four data above is a type of mixed code into (inner code mixing). It can be proved by the use of words derived from the local language, namely the Java language. The words are lek, yo, mbulet, and nyunggih. The word lek means 'if'. In the word yo, often used in communicating orally that serves to assert. The word mbulet means 'less clear', and the word nyunggih means 'to bring on the head'.

\section{2) Outer Code Mixing}

e) My name is Gradis NIM ... 57, I want to ask in the language slide and social level of society.

f) I used to be yes, e ... my name is Nikmatus NIM two I asked in the speech acting section was divided into three locations, illocution, and perlokusi, well there i want to ask e ... real example for all three types this? What is that? That's all thanks.

g) But here I ask is the relationship bilingualisme with diglosia, iyes diglosia, diglosia.

h) All right, that's an explanation from group one. This time we open a question session. E .... Sorry sorry.

The four data above is kind of mixed out of code (outer code mixing). It can be proved by the use of words that come from a foreign language, namely English. Those words are slides, real, iyes, and sorry. The word slide means 'impressions', the word real means 'real or actual', the word iyes means 'yes', and the word sorry means 'sorry'.

\section{B. $\quad$ Causes of Mixed Codes}

The cause of the code interference in the data (a) and (b) above is due to linguistic type. This is because speakers come from the Javanese tribe so the word yo used in everyday conversation. Therefore, unintentionally the word appears. With the use of Javanese language, it is expected opponent said more understand that is meant because the words are easy to remember.

Data (c) and (d) there is also the cause of code interference caused by the attitudinal type. This happens because students come from the tribe of PBSI Java so often slip Java language in communicating. This is because the word mbulet and nyunggih more stable meaning. With the use of both words, it is expected opponent said easy to understand the meaning to be conveyed speakers. In addition, both words are used to indicate the speaker's ability in diction use.

The cause of the code interruption in the data (e) above is due to the attitudinal type. This is because the word slide is the 
mention of the word 'impressions' on the power point. Power point is a means of technology commonly used by students to expose the material. Speakers still use the word slide because the word impression is generally longer, while the slide is shorter in duration. Thus, the word slide is more appropriate than the impression. Thus, speakers show the ability to choose the right words.

In the data (f) and (g), the cause of the code interruption due to attitudinal type. The use of the word real and iyes is due to the speaker wants to show the ability in using English. Similarly with data (h), the cause of the code interruption due to attitudinal type. The word sorry is used to refine the phrase. Although the word comes from English, it is often used in communicating.

Based on the above explanations, the kind of code mix used by PBSI students is to mix code into (inner code mixing) and mix the code out (outer code mixing). The language used in mixing the code into is the Java language. In general, PBSI students come from the Javanese tribe. The type of mixed outof-code (outer code mixing) used by PBSI students is English. That's because English is an international language so many students are familiar with the language. Besides that, foreign language which is more mastered by PBSI students is English.

Causes of mixed data code above there are two, namely linguistic type and attitudinal type. The linguistic factor occurs because the Java language is easier to remember. This is because generally the students come from the Javanese. Whereas, attitudinal type occurs because PBSI students want to show their ability in using English. In addition, English is used to select words that are judged to mean more relevance.

\section{CONCLUSION}

Based on the results of data analysis, can be concluded as follows. First, the type of code mix found is to mix code into (inner code mixing) and mix the code out (outer code mixing).
Second, the cause of the mixed code because linguistic type and attitudinal type.

\section{References}

Aslinda \& Syafyahya. (2007). Pengantar Sosiolinguistik. Bandung: PT Refika Aditama.

Chaer, A. (2012). Linguistik umum. Jakarta: Rineka Cipta.

Chaer, A. \& Agustina, L. (2004). Sosiolinguistik: Perkenalan awal. Jakarta: Rineka Cipta.

Kridalaksana, H. (2001). Kamus Linguistik. Jakarta: PT Gramedia Pustaka Utama.

Rahardi, Kunjana. (2001). Sosiolinguistik, Kode dan alih kode. Yogyakarta: Pustaka Pelajar (Anggota IKAPI).

Rokhman, Fathkur. (2013). Sosiolinguistik, Suatu pendekatan pembelajaran bahasa dalam masyarakat multikultural. Yogyakarta: Graha Ilmu.

Saddhono, Kundharu. (2012). Pengantar Sosiolinguistik (Teori dan konsep dasar). Surakarta: Universitas Sebelas Maret Press.

Sumarsono. (2002). Sosiolinguistik. Yogyakarta: Pustaka Pelajar.

Sutomo, E. (2007). 9 presentasi kreatif dengan Power Point 2007. Yogyakarta: Andi Offset

Suwandi, S. (2010). Serba Linguistik (Mengupas pelbagai praktik bahasa). Surakarta: Universitas Sebelas Maret Press.

Suwito. (1983). Pengantar awal Sosiolingusitik. Surakarta: Henry Offset.

Triwahyuni, T., C. \& Kadir, A. (2004). Presentasi Efektif dengan Microsoft Power Point. Yogyakarta: Andi Offset.

Triwidodo, T. \& Kristanto, D. (2004). Pengembangan Kepribadian Sekretaris. Jakarta: Gramedia 